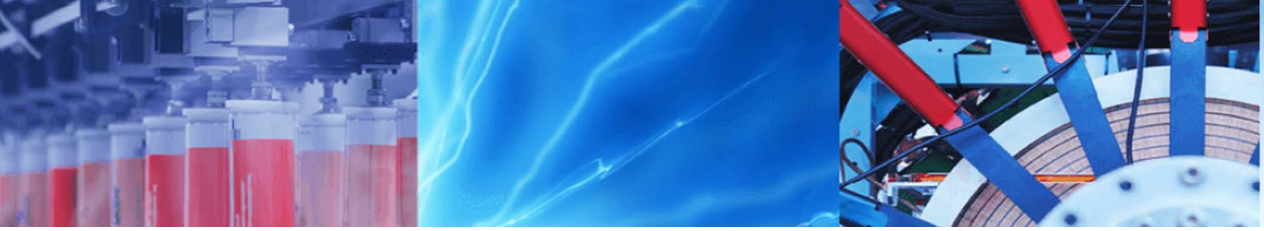

Research Article

\title{
Properties and characterization of an aluminium-silicon nitride fibre powder metal composite
}

\author{
T. Dougherty ${ }^{1}$ (i) $\cdot Y . \mathrm{Xu}^{1}{ }^{10}$ \\ (c) Springer Nature Switzerland AG 2018
}

\begin{abstract}
In this article, we fabricated one-dimensional 0.5 vol\% silicon nitride $\left(\mathrm{Si}_{3} \mathrm{~N}_{4}\right)$ fibre reinforced Alumix 123 matrix composites by the powder metallurgy method. $\mathrm{Si}_{3} \mathrm{~N}_{4}$ is a ceramic material with high strength, stiffness and low coefficient of thermal expansion. The $\mathrm{Si}_{3} \mathrm{~N}_{4}$ used in the study is comprised of single crystal fibres with sub-micrometre diameter and length $<25 \mu \mathrm{m}$. The size of the fibre is smaller than the metal matrix powder allowing it to coat the metal powder before consolidation rather than forming agglomerations that might lead to pores and poor mechanical properties. We investigated the effects of $\mathrm{Si}_{3} \mathrm{~N}_{4}$ fibre additions on the densification, hardness, elastic modulus and tensile strength. The experimental results found that the $\mathrm{Si}_{3} \mathrm{~N}_{4}$ fibre effectively enhanced the mechanical properties of the composites at low additions. The microstructural analysis clearly shows the $\mathrm{Si}_{3} \mathrm{~N}_{4}$ fibres in the sintered grain boundaries. The interface between the fibre and the Alumix123 matrix showed good wetting and bonding with only minimal reaction. The $\mathrm{Si}_{3} \mathrm{~N}_{4}$ fibre reinforced Alumix 123 composites have potential uses in the automobile and aerospace industries due to their improved specific mechanical properties.
\end{abstract}

Keywords Alumix123 composite $\cdot$ Silicon nitride $\cdot$ Fibre $\cdot$ Mechanical properties $\cdot$ Microstructure

\section{Introduction}

In the past few years, the development of aluminium metal matrix composites (MMCs) has attracted significant attention due to a combination of their low density, good thermal and electrical conductivities, high hardness and enhanced mechanical strength. The property suite of MMCs creates the potential for numerous applications such as in the automobile, aerospace, marine and defence industries [1-3]. The properties of the composites can be tailored through the addition of selected ceramic reinforcements such as metallic oxides, carbides, borides and nitrides [3-7]. The most commonly used reinforcements are in the form of particles, continuous \& discontinuous whisker, and fibres, with sizes ranging from $10 \mathrm{~nm}$ up to $500 \mu \mathrm{m}[1,8-10]$. Among them, short fibres have been attracting growing interest [11-13]. Short fibre reinforced
MMCs have been found to have better mechanical properties than that of particles reinforced MMCs [11].

Continuous fibre reinforcements can achieve rule-ofmixtures composite properties in the direction which the fibres are oriented in composite structures in, for example, pultruded composites. For more complicated structures, fibre laminates, woven structures, composites utilise long fibres to achieve maximum composite properties at high fibre loadings; often more than $60 \%$ fibre. Long fibres and complicated manufacturing processes lead to high-cost parts. Many of these structures suffer from anisotropy in at least one direction leading to complex design requirements which further increase costs, for example, finite element analysis. Furthermore, infusion processes also require a matrix with low-viscosity for complete infiltration which is achievable in the polymer industry, but liquid metals are often highly reactive to reinforcements.

T. Dougherty, troy.dougherty@nuenz.com | ${ }^{1}$ Nuenz Limited, 68 Gracefield Rd, Lower Hutt 5010, New Zealand.

SN Applied Sciences (2019) 1:135 | https://doi.org/10.1007/s42452-018-0147-z 
Early MMCs used $\mathrm{SiC}$ and $\mathrm{Al}_{2} \mathrm{O}_{3}$ particulate reinforcements due to their ease of availability as material from the abrasives industry. $\mathrm{SiC}$ and $\mathrm{Al}_{2} \mathrm{O}_{3}$ are both unstable in aluminium alloys. $\mathrm{SiC}$ reacts with aluminium to form the brittle phase $\mathrm{Al}_{4} \mathrm{C}_{3}$ and $\mathrm{Al}_{2} \mathrm{O}_{3}$ reacts with alloying $\mathrm{Mg}$ to form $\mathrm{MgO}$ or $\mathrm{MgAl}_{2} \mathrm{O}_{4}$. Historically, modifying the alloy chemistry was successful to stabilise these reinforcements, but it puts constraints on the alloy chemistries, processing and further tempering [14]. $\mathrm{SiC}$ and $\mathrm{Al}_{2} \mathrm{O}_{3}$ remain the two most common reinforcements in aluminium for this historical reason, with $\mathrm{SiC}$ significantly more popular. There are three reasons for exploring additional composite reinforcements. Firstly, historical reinforcements are synthesised in bulk, in processes such as the Acheson process, producing bulk crystalline materials. These are then ground to small sizes for use in MMCs. The sharp angular crystals are abrasive on the tooling used in the composite industry leading to high wear and costs. Secondly, the chemistry is unfavourable for traditional aluminium alloys. The most common alloys are 2024, 7075 and 6061 of which only 6061 has $0.6 \% \mathrm{Si}$ in its specification, and 2024 and 7075 have 1.5 and $2.5 \mathrm{Mg}$, respectively. There is increasing interest now in inherently compatible materials such as AIN and $\mathrm{Si}_{3} \mathrm{~N}_{4}$ of which AIN is inherently stable and $\mathrm{Si}_{3} \mathrm{~N}_{4}$ forms thin, stable AIN or SiAION boundary layers $[15,16]$. Lastly, is the utilisation of fibrous reinforcements for improved performance both continuous for high-value applications and discontinuous-short fibre reinforcements for high-volume applications $[17,18]$.

In this study, we investigated $\mathrm{Si}_{3} \mathrm{~N}_{4}$ discontinuous fibre reinforcements with the aim to improve mechanical properties while retaining ductility and inherent metallicity. $\mathrm{Si}_{3} \mathrm{~N}_{4}$ is a low density $\left(3.1 \mathrm{~g} / \mathrm{cm}^{3}\right)$ ceramic material with high mechanical strength and hardness, good thermal and chemical stability, and good wear and corrosion resistance. It is of current interest as reinforcement in the manufacturing of MMCs [19-22]. Several works have been reported on fabrication and mechanical characterisation of aluminium matrix composite reinforced with $\mathrm{Si}_{3} \mathrm{~N}_{4}$ particles. AA6082 matrix composites reinforced with $\mathrm{Si}_{3} \mathrm{~N}_{4}$ manufactured by the stircasting process showed an increase in density, hardness and tensile strength with increased content of $\mathrm{Si}_{3} \mathrm{~N}_{4}$ [19]. AA6061 matrix composites reinforced with nickel coated $\mathrm{Si}_{3} \mathrm{~N}_{4}$ manufactured by the liquid metallurgy route resulted in higher tensile strength than that of pure AA6061 [2]. Pure $\mathrm{Al} / \mathrm{Si}_{3} \mathrm{~N}_{4}$ composite manufactured by pressure infiltration improved the bending strength compared to conventional 2024Al alloy [20]. Al/ $/ \mathrm{Si}_{3} \mathrm{~N}_{4}$ composite manufactured by powder metallurgy technique showed improved hardness and transverse rupture strength by increasing the volume fraction of $\mathrm{Si}_{3} \mathrm{~N}_{4}$ particles [21]. More recently, $\beta-\mathrm{Si}_{3} \mathrm{~N}_{4}$ whiskers reinforced pure $\mathrm{Al}$ composites manufactured by hot-pressing method indicated an increase in tensile and ductility with the loading of $\mathrm{Si}_{3} \mathrm{~N}_{4}$ [17]. To our knowledge, none of the researchers used $\mathrm{a}-\mathrm{Si}_{3} \mathrm{~N}_{4}$ fibre as reinforced materials and no work has been reported on mechanical properties and microstructure of $\mathrm{a}-\mathrm{Si}_{3} \mathrm{~N}_{4}$ fibre reinforced Alumix $123 \mathrm{com}$ posites, especially at low addition levels.

In the present study, we fabricated 0.5 vol\% a- $-\mathrm{Si}_{3} \mathrm{~N}_{4}$ fibre reinforced Alumix 123 composites by powder metallurgy (PM). The effects of high-aspect-ratio $\mathrm{Si}_{3} \mathrm{~N}_{4}$ on the sintering behaviour, mechanical properties and microstructure of the composites were investigated.

\section{Experimental}

\subsection{Materials}

The base aluminium alloy powder used was the commercial Alumix123 powder (Al-4.5Cu-0.7Si-0.5 Mg-1.5 acrawax, density of $2.77 \mathrm{~g} / \mathrm{cm}^{3}$, Ecka Granules Germany). The $\mathrm{Si}_{3} \mathrm{~N}_{4}$ fibre was $>95 \% \mathrm{Si}_{3} \mathrm{~N}_{4}>80$ vol\% fibre (dominant a-phase, Nuenz Limited New Zealand).

\subsection{Fabrication of Alumix $123 / \mathrm{Si}_{3} \mathrm{~N}_{4}$ composite}

Alumix123 powders were dry mixed with 0.5 vol\% $\% \mathrm{Si}_{3} \mathrm{~N}_{4}$ fibre. The powders were then poured into a die, and uniaxially cold pressed at a pressure of $300 \mathrm{MPa}$. The green specimens were then sintered in a horizontal tube furnace under a nitrogen atmosphere (dew point below $-60^{\circ} \mathrm{C}$ ) at $600^{\circ} \mathrm{C}$ for $1 \mathrm{~h}$. The surfaces of sintered pellets were lightly polished in the normal manner. For comparison, pure Alumix123 (Alumix123-ref) were manufactured by the same process. Figure 1 illustrates the $\mathrm{Al} / \mathrm{Si}_{3} \mathrm{~N}_{4}$ composite synthesis procedure in this work.

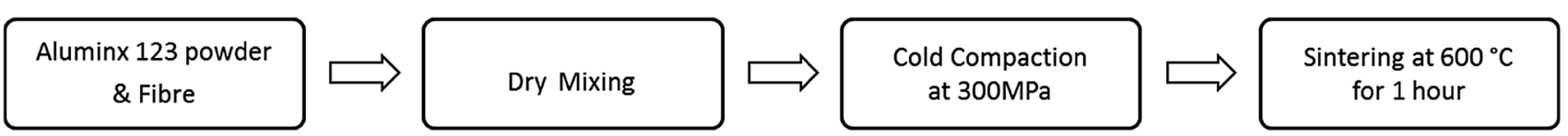

Fig. 1 Schematic presentation of the synthesis for $\mathrm{Al} / \mathrm{Si}_{3} \mathrm{~N}_{4}$ fibre composite 


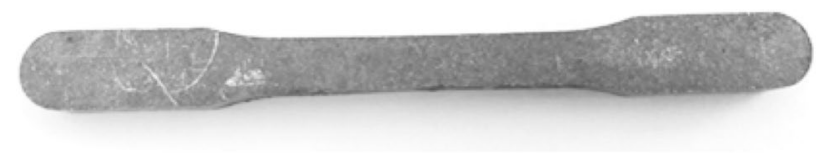

Fig. 2 Image of a sintered tensile bar

\section{Characterization}

The densities of the sintered specimens were measured by the Archimedes method according to MPIF Standard 42. Hardness's of all specimens were measured by the Rockwell hardness on the B scale (HRB, ASTM E18) and mean of at least 10 readings was taken. Ultrasonic modulus was measured and calculated according to ASTM E494. Ultimate tensile strength (UTS) measurements were carried out using a specimen as per ASTM E8, B925 using Fig. 19 unmachined dogbones. Figure 2 shows a picture of the as-sintered tensile bar. All mechanical properties were measured in the T1 condition as per ASTM E8. At least five tests were conducted under the same conditions to ensure the reliability of the results. Microstructures of Alumix 123/ $\mathrm{Si}_{3} \mathrm{~N}_{4}$ composites were carried out by scanning electron microscopy (FEI Nova NanoSEM 450) with energy dispersive X-ray spectroscopy (EDS), and by optical microscopy.

\section{Results and discussion}

\subsection{Materials}

Table 1 shows a particle size distribution analysis of the $\mathrm{Si}_{3} \mathrm{~N}_{4}$ fibres which are comprised of $80 \%$ fibrous material by weight or volume (as shown in Fig. 3). The remaining $20 \%$ is $\mathrm{Si}_{3} \mathrm{~N}_{4}$ particulate. A full analysis of the fibres has been previously reported by the authors [23]. The surface area of the fibres was previously reported as $4.04 \mathrm{~m}^{2} / \mathrm{g}$ [24] while the surface area of Alumix 123 was calculated to be $0.02-0.03 \mathrm{~m}^{2} / \mathrm{g}$ from the manufacturer's specifications.

\subsection{Green and sintered density}

Table 2 shows the green and sintered densities of Alref and $\mathrm{Al} / \mathrm{Si}_{3} \mathrm{~N}_{4}$ composites. The green and sintered

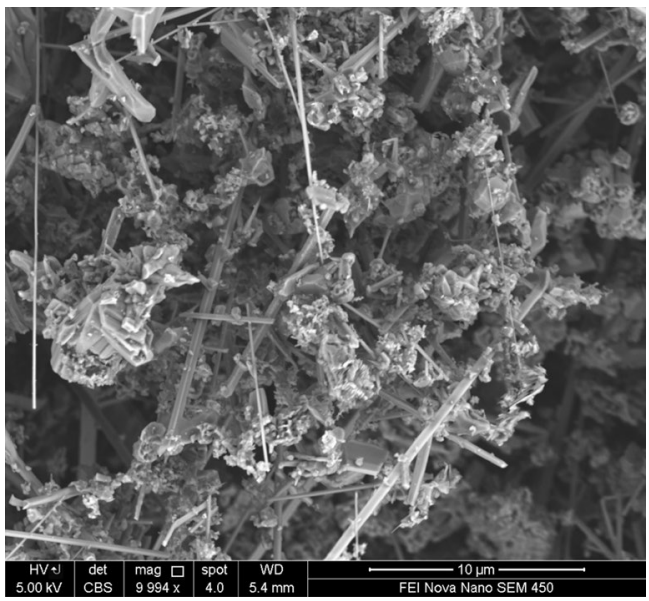

Fig. 3 SEM image of $\mathrm{Si}_{3} \mathrm{~N}_{4}$ fibres

Table 2 Green and Sintered density of Al-ref and 0.5 vol\% and $1 \mathrm{vol} \%$ of $\mathrm{Al} / \mathrm{Si}_{3} \mathrm{~N}_{4}$

\begin{tabular}{llll}
\hline Sample & Green density $\left(\mathrm{g} / \mathrm{cm}^{3}\right)$ & $\begin{array}{l}\text { Sintered } \\
\text { density }(\mathrm{g} / \\
\left.\mathrm{cm}^{3}\right)\end{array}$ & $\begin{array}{l}\text { Volume } \\
\text { shrinkage } \\
(\%)\end{array}$ \\
\hline Al-ref & $2.62 \pm 0.01$ & $2.76 \pm 0.01$ & 4.2 \\
$\mathrm{Al} / 0.5 \mathrm{vol} \% \mathrm{Si}_{3} \mathrm{~N}_{4}$ & $2.62 \pm 0.01$ & $2.75 \pm 0.01$ & 3.8 \\
$\mathrm{Al} / 1 \mathrm{vol} \% \mathrm{Si}_{3} \mathrm{~N}_{4}$ & $2.62 \pm 0.01$ & $2.74 \pm 0.01$ & 3.8 \\
\hline
\end{tabular}

densities of pure Alumix 123 were $2.62 \pm 0.01 \mathrm{~g} / \mathrm{cm}^{3}$ and $2.76 \pm 0.01 \mathrm{~g} / \mathrm{cm}^{3}$, respectively, which were comparable with other investigations and the manufacturer's specifications [25]. The green and sintered densities of composites were similar to that of the reference. The density comparison indicated that 0.5 vol\% of fibres did not significantly impact compaction and densification processes, in fact, it was within the experimental margin of error. Nearly full density ( $>99 \%$ of theoretical density) was obtained after sintering for both Al-ref and $\mathrm{Al} / \mathrm{Si}_{3} \mathrm{~N}_{4}$ composites. A preliminary investigation was carried out into 1 vol\% addition of fibre in Alumix 123. The green and sintered densities of $\mathrm{Al} / 1 \mathrm{vol} \% \mathrm{Si}_{3} \mathrm{~N}_{4}$ were $2.62 \pm 0.01 \mathrm{~g} / \mathrm{cm}^{3}$ and $2.74 \pm 0.01 \mathrm{~g} /$ $\mathrm{cm}^{3}$, respectively. The density of $\mathrm{Si}_{3} \mathrm{~N}_{4}$ fibres was measured to be $3.1 \mathrm{~g} / \mathrm{cm}^{3}$ (Method modified from ASTM D0167) and, therefore, the theoretical density for this sample was $2.78 \mathrm{~g} / \mathrm{cm}^{3}$. It was evident that the higher addition of $\mathrm{Si}_{3} \mathrm{~N}_{4}$
Table 1 Size distribution of Si3N4 fibre

\begin{tabular}{|c|c|c|c|c|c|c|}
\hline \multirow{2}{*}{$\begin{array}{l}\mathrm{Si}_{3} \mathrm{~N}_{4} \text { (80 vol\% fiber and } 20 \\
\text { vol\% particles) }\end{array}$} & \multicolumn{3}{|c|}{$\mathrm{D}(\mu \mathrm{m})$} & \multicolumn{3}{|c|}{$L(\mu m)$} \\
\hline & $d_{10}$ & $d_{50}$ & $d_{90}$ & $d_{10}$ & $d_{50}$ & $d_{90}$ \\
\hline Fibre size & 0.12 & 0.36 & 0.66 & 3 & 14.5 & 27.6 \\
\hline Particulate size & 0.06 & 0.15 & 0.28 & - & & \\
\hline
\end{tabular}


fibre affected the sintering process and, therefore, we did not carry out mechanical testing in this study.

\subsection{Mechanical properties}

\subsubsection{Hardness}

The hardness of Al-ref and $\mathrm{Al} / \mathrm{Si}_{3} \mathrm{~N}_{4}$ composites were measured to be $28 \pm 3 \mathrm{HRB}$ and $36 \pm 3 \mathrm{HRB}$, respectively. This is a significant increase in hardness. Hardness is a combination of many mechanical properties, including toughness, strength and stiffness, and can be a good indication of wear resistance. Specific wear properties were not measured in this investigation as an application specific wear test must be identified to be applicable. Wear testing was planned as a part of future, application specific research.

\subsubsection{Elastic modulus}

The elastic modulus of Al-ref and $\mathrm{Al} / \mathrm{Si}_{3} \mathrm{~N}_{4}$ composites were measured as $68.5 \pm 1.7 \mathrm{GPa}$ and $77.1 \pm 1.1 \mathrm{GPa}$, respectively. Models for improved modulus are well known for fibre reinforcement of matrices. The improvement here is beyond the rule of mixtures if the modulus for $\mathrm{Si}_{3} \mathrm{~N}_{4}$ is assumed to be $310 \mathrm{GPa}$. The fibres here were singlecrystalline, and $310 \mathrm{GPa}$ is the commonly stated sintered, polycrystalline $\mathrm{Si}_{3} \mathrm{~N}_{4}$ modulus. The $13 \%$ increase in modulus from a 0.5 vol\% addition indicates additional stiffening mechanisms or a significantly higher stiffness in the fibres compared to the expected rule of mixtures value. An increase in modulus is of significant interest as alloying to increase the modulus typically increases the density. Here we see a potential for a significant increase in the specific modulus through small additions of $\mathrm{Si}_{3} \mathrm{~N}_{4}$ fibre.

\subsubsection{Tensile properties}

Figure 4 presents a representative tensile curve for both Alref and $\mathrm{Al} / \mathrm{Si}_{3} \mathrm{~N}_{4}$ composite. The average UTS of the reference and composites were $192 \pm 11 \mathrm{MPa}$ and $212 \pm 10 \mathrm{MPa}$, respectively. The yield strength (YS) of the composites also increased from $115 \pm 17 \mathrm{MPa}$ to $136 \pm 18 \mathrm{MPa}$. The elongation of the composites slightly decreased from $3.0 \pm 1.0$ to $2.8 \pm 0.4 \%$. The tensile values demonstrated that the addition of hard $\mathrm{Si}_{3} \mathrm{~N}_{4}$ reinforcement increases the strength of the Alumix 123 matrix through increased resistance to tensile stresses [22], with a minor reduction in ductility. The larger (than expected) variation in the tensile test results is due to the nature of the PM test specimens which are unmachined.

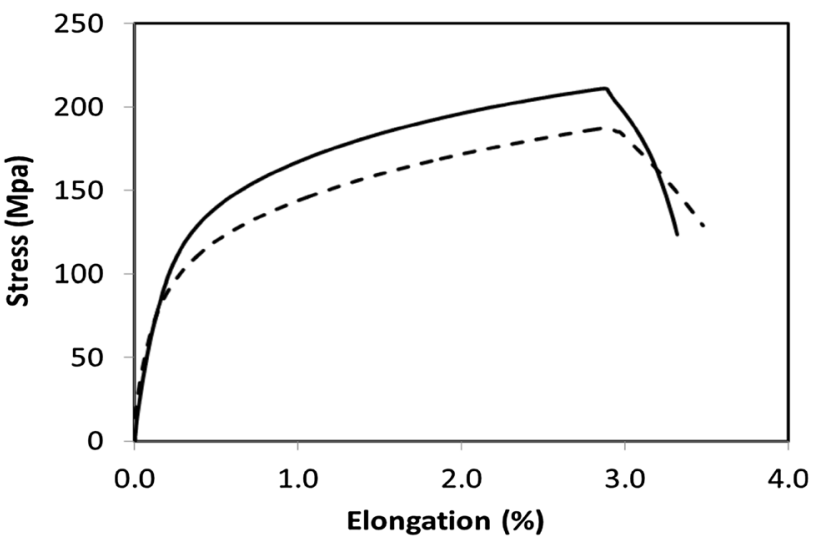

Fig. 4 Typical tensile stress-strain curves of Al-ref (- - -) and $\mathrm{Al} / \mathrm{Si}_{3} \mathrm{~N}_{4}$ composite (一)

\subsection{Microstructure}

Figure $5 \mathrm{a}$, b show optical microscopy images of Al-ref and $\mathrm{Al} / \mathrm{Si}_{3} \mathrm{~N}_{4}$ composite, respectively, (etched aggressively using a corrosive $\mathrm{NaF} / \mathrm{NaOH}$ etch). The micrographs show that there was no notable difference between the arrangements of the grains. Both specimens shows good densification which is consistent with the density measurement results reported earlier. A calculation was performed on the relative surface area of the $\mathrm{Si}_{3} \mathrm{~N}_{4}$ reinforcement and Alumix 123 . At $0.5 \%$ addition, it was determined that this was proportional to a monolayer coverage of the Alumix $123\left(\mathrm{SSA}_{\text {addivite }} \times\right.$ vol.\% $\left.=\mathrm{SSA}_{\text {matrix }}\right)$ [24] taking into account that a cohesive monolayer of a solid on another solid is unrealistic. Following this calculation, excess solid reinforcement will lead to agglomeration of ceramic reinforcement and it is possible that this is a reason why $1 \% \mathrm{Si}_{3} \mathrm{~N}_{4}$ composites demonstrated less densification than $0.5 \%$. Common sintering temperatures for $\mathrm{Si}_{3} \mathrm{~N}_{4}$ are $>1400{ }^{\circ} \mathrm{C}$ so there will be negligible stage 1-2 ceramic sintering at $600^{\circ} \mathrm{C}$ to reduce the porosity caused by agglomerations. Therefore, any agglomeration of $\mathrm{Si}_{3} \mathrm{~N}_{4}$ additive caused by excessive additive additions or non-uniform dispersion should present in the final microstructure as increased porosity or reduced densification; porosity that would be focused around agglomerations of $\mathrm{Si}_{3} \mathrm{~N}_{4}$ that were not sintered at $600{ }^{\circ} \mathrm{C}$. None of these phenomena were observed in either the microstructural evaluation or the evaluation of the density above.

Microstructural evaluation of the grain boundary etched under HF identified many inclusions with different chemistries. Back-scatter (BS) mode was used to identify which phases had different element density and removed them from consideration; the main strengthening phase in 2XXX alloy is based on $\mathrm{Cu}$ and was easily identified using $\mathrm{BS}$ due to its high electron density. $\mathrm{Al}$ and $\mathrm{Si}_{3} \mathrm{~N}_{3}$ were not 

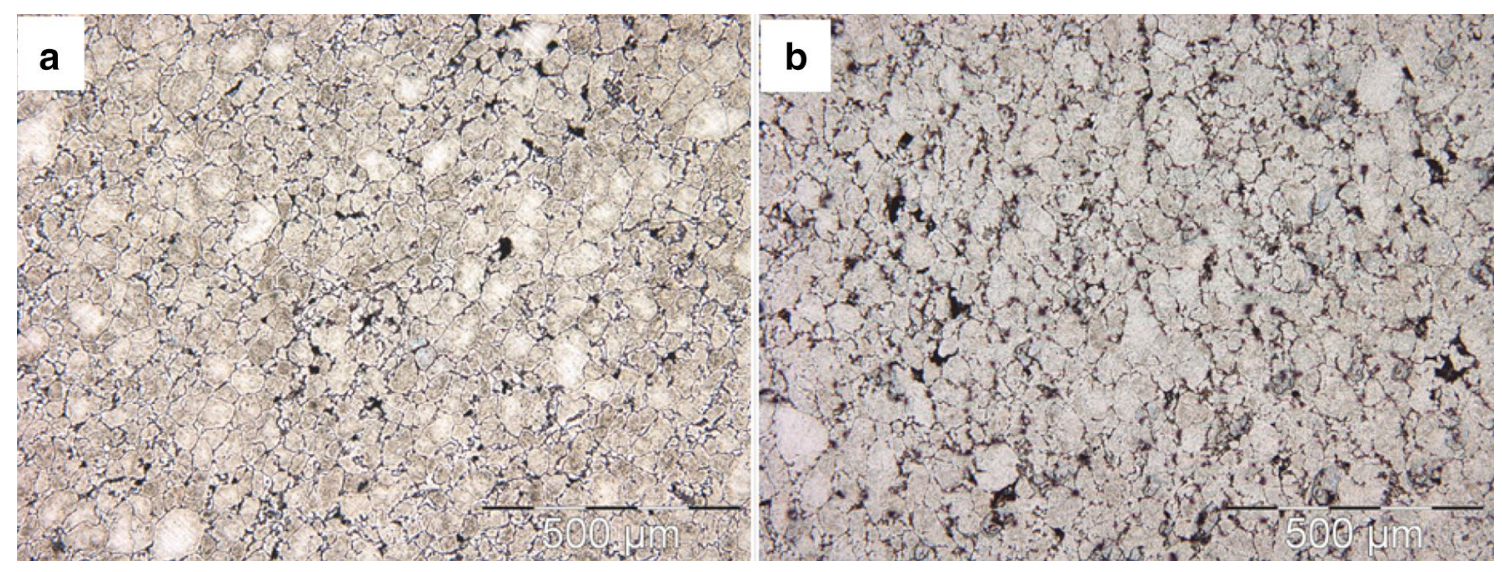

Fig. 5 Optical microscopy of a sintered Al-ref and $\mathbf{b} \mathrm{Al} / \mathrm{Si}_{3} \mathrm{~N}_{4}$ composite

easily identified by contrast imaging owing to their similar electron density. Despite this, in a typical image shown in Fig. 6, many $\mathrm{Si}_{3} \mathrm{~N}_{4}$ inclusions with the expected diameter between 60 and $900 \mathrm{~nm}$ were observed. EDS identified that the aluminium matrix was mostly devoid of Si and $\mathrm{N}$ and that these elements could be identified at elevated concentrations in the $\mathrm{Si}_{3} \mathrm{~N}_{4}$ inclusions. These inclusions were 100-900 nm in diameter which was consistent with the size analysis of the original $\mathrm{Si}_{3} \mathrm{~N}_{4}$. This size was at the resolution limit of the EDS detector, so the matrix elements also bled into the EDS spectra. Figure 6 provides a typical SEM/BS image with EDS of the matrix and a typical inclusion. The lighter phases in the image showed elevated Cu which had migrated to the grain boundary. There was no observable porosity between the $\mathrm{Si}_{3} \mathrm{~N}_{4}$ and either the aluminium matrix or the alloy inclusions which indicated good wetting by the matrix. The $\mathrm{Si}_{3} \mathrm{~N}_{4}$ presented as discrete inclusions along the grain boundary. It was not
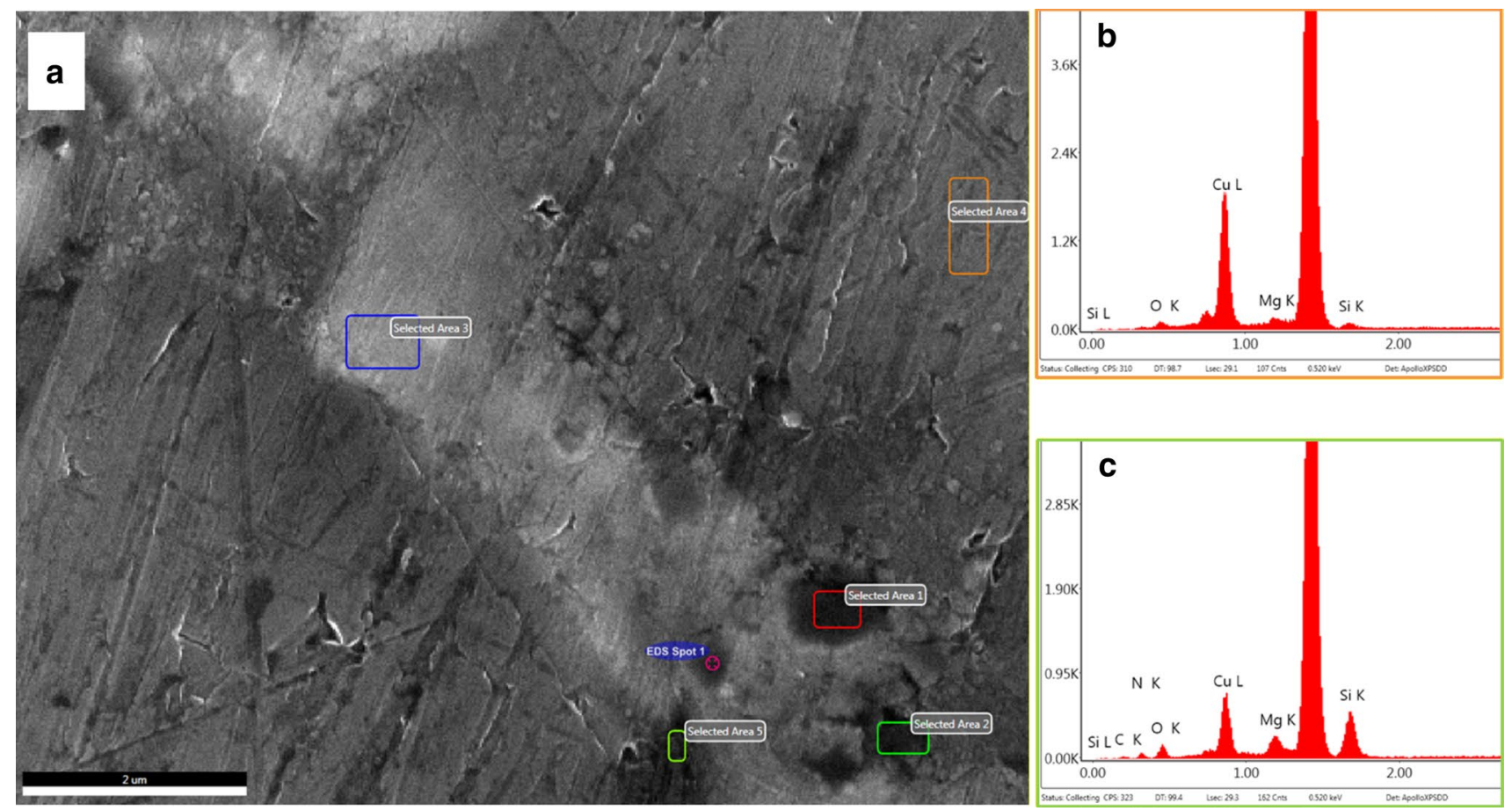

Fig. 6 SEM/BS image of the cross-section of the composite with EDS areas indicated and selected EDS spectra inset: a SEM/BS image of a typical grain boundary, b EDS of selected area 4 of a showing aluminium matrix, c EDS of selected area 2 showing increased $\mathrm{Si}$ and $\mathrm{N}$ elemental concentrations above matrix elements of $\mathbf{b}$ 
possible to determine if these were from the particulate content of the $\mathrm{Si}_{3} \mathrm{~N}_{4}$ of fibres oriented perpendicular to the imaging plane as the HF sample had only been lightly etched.

The SEM cross-section of the $\mathrm{Al} / \mathrm{Si}_{3} \mathrm{~N}_{4}$ composite (Fig. 7a) reveals that the fibres have survived thermal processing in the composite. The EDS results (Fig. 7b, c) indicate that the chemical composition of the fibres is $\mathrm{Si}_{3} \mathrm{~N}_{4}$ as expected.

HR-SEM images in Fig. 8a, $b$ further depicts the morphology of the grain boundary. The grain boundary was aggressively and deeply etched using Weck's reagent which caused digestion of MgAl species but left $\mathrm{CuAl}_{x}$ and $\mathrm{Si}_{3} \mathrm{~N}_{4}$ for observation. In Fig. $8 \mathrm{a}$, a $\mathrm{Si}_{3} \mathrm{~N}_{4}$ fibre is observed lying inside and along the grain boundary. The fibre is bound to the Alumix 123 matrix. The surface of the fibre is clean and does have a'digested' appearance, proving that there is a well-bonded interface between $\mathrm{Si}_{3} \mathrm{~N}_{4}$ fibre and Alumix123 matrix. It is known that the moderate interfacial reaction and enhanced interfacial bonding between matrix and reinforcement result in improved mechanical properties of composites. $[2,26]$ A reaction of a few atomic
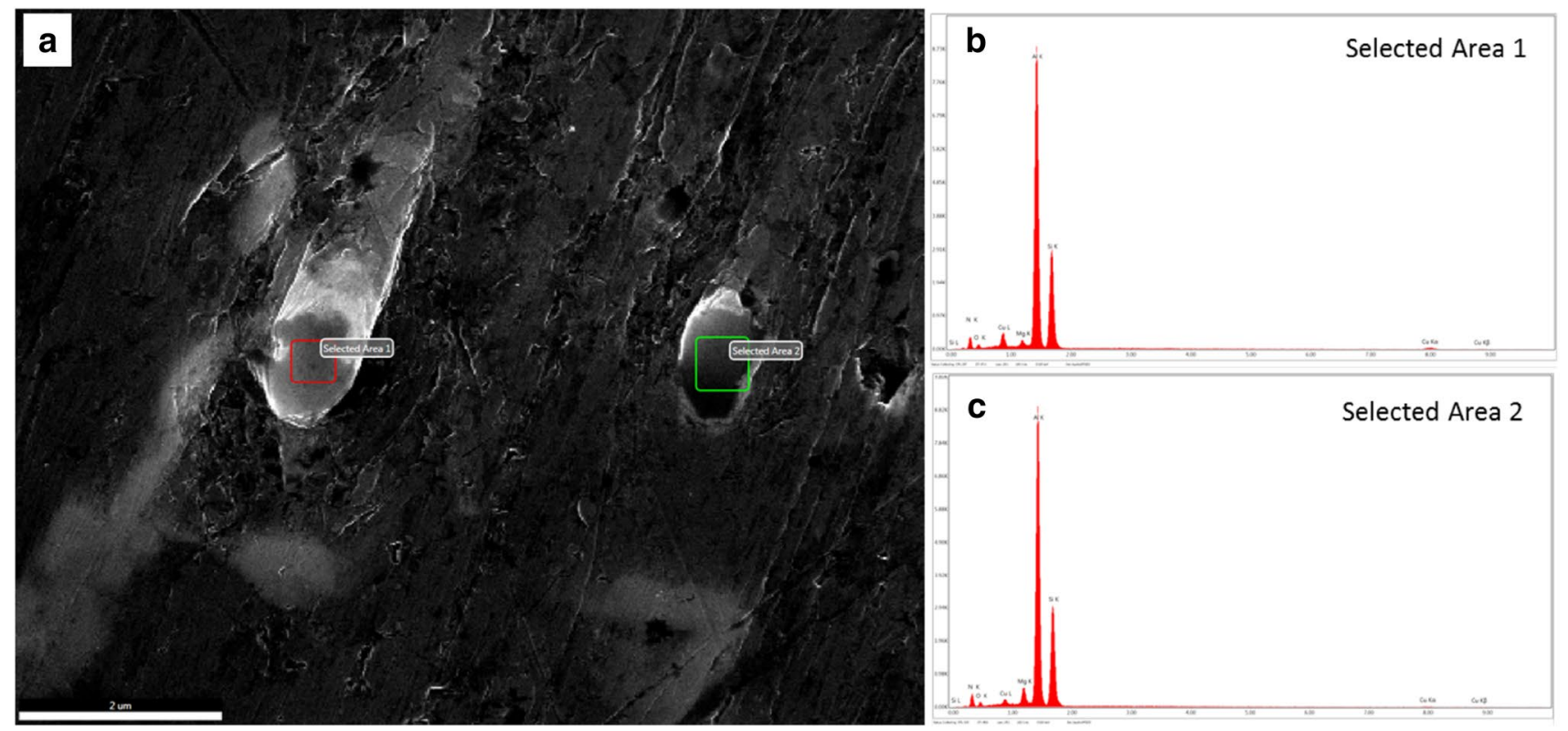

Fig. 7 a SEM image of the cross-sectional of the composite specimen; $\mathbf{b}$ and $\mathbf{c}$ EDS analysis of the selected area 1 and 2
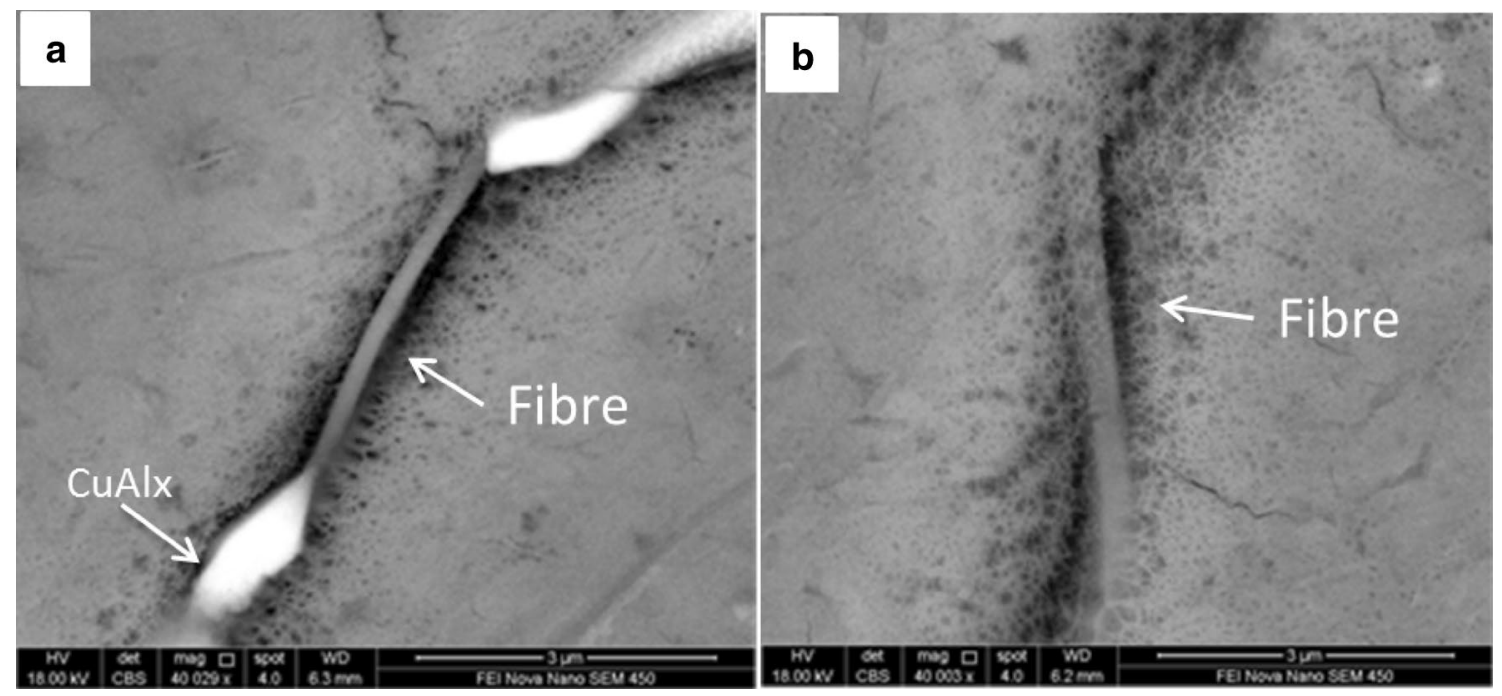

Fig. 8 SEM images of the grain boundary of composite (Etching Weck) 
layers or wetting is required to bind the reinforcement to the matrix intimately. The improved hardness, modulus and UTS indicate that the fibres have bonded with the matrix to form the strong interphase required for load transfer without significant reaction to cause loss of ductility through the formation of undesirable by-products. Furthermore, good density has been achieved-evident through the density analysis and the low-magnification images - which are critical for achieving good mechanical properties considering the use of pressureless sintering in this study.

\section{Conclusion}

In this study, 0.5 vol\% $\mathrm{Si}_{3} \mathrm{~N}_{4}$ fibre-reinforced Alumix 123 matrix composites were successfully fabricated using pressureless sintering under dry nitrogen. The composites exhibit higher hardness ( $36 \pm 3 \mathrm{HRB}$ ), elastic modulus $(77.1 \pm 1.1 \mathrm{GPa})$, UTS $(212 \pm 10 \mathrm{MPa})$ and YS $(136 \pm 18 \mathrm{MPa})$ and only slightly lower elongation ( $2.8 \pm 0.4 \%)$, compared with the Aluminium reference. The enhanced mechanical properties of $\mathrm{Al} / \mathrm{Si}_{3} \mathrm{~N}_{4}$ composite were attributed to the effective load transfer from the Alumix 123 matrix to the hard $\mathrm{Si}_{3} \mathrm{~N}_{4}$ fibre via good interface bonding. The microstructural analysis revealed easily recognised $\mathrm{Si}_{3} \mathrm{~N}_{4}$ fibres were lying at the grain boundaries. The results obtained above suggest that $\mathrm{Si}_{3} \mathrm{~N}_{4}$ fibres are expected to play a promising reinforcement role for MMCs.

\section{Compliance with ethical standards}

Conflict of interest This study was funded by Nuenz Limited, and the authors are in full-time employment for Nuenz Limited.

\section{References}

1. Kumar D, Agnihotri G, Purohit R (2015) Advanced aluminium matrix composites: the critical need of automotive and aerospace engineering fields. Mater Today Proc 2:3032-3041

2. Rahimian M, Ehsani N, Parvin N, Baharvandi HR (2009) The effect of particle size, sintering temperature and sintering time on the properties of $\mathrm{Al}-\mathrm{Al}_{2} \mathrm{O}_{3}$ composites, made by powder metallurgy. J Mater Process Technol 209:5387-5393

3. Boostani AF, Tahamtan S, Jiang ZY, Wei D, Gong D (2015) Enhanced tensile properties of aluminium matrix composites reinforced with graphene encapsulated $\mathrm{SiC}$ nanoparticles. Compos Part A 68:155-163

4. Ramesh C, Keshavamurthy R, Channabasappa B, Ahmed A (2009) Microstructure and mechanical properties of Ni-P coated $\mathrm{Si}_{3} \mathrm{~N}_{4}$ reinforced Al6061 composites. Mater Sci Eng A 502:99-106

5. Pramanik A (2016) Effects of reinforcement on wear resistance of aluminum matrix composites. Trans Nonferrous Met Soc China $26: 348-358$
6. Jiru WG, Sankar MR, Dixit US (2017) Investigation of microstructure and microhardness in laser surface alloyed aluminium with $\mathrm{TiO}_{2}$ and $\mathrm{SiC}$ powders. Mater Today Proc 4:717-724

7. Prasad Reddy A, Vamsi Krishna P, Narasimha Rao R, Murthy NV (2017) Silicon carbide reinforced aluminium metal matrix nano composites-a review. Mater Today Proc 4:3959-3971

8. Chou TW, Kelly A, Okurat A (1985) Fibre-reinforced metal matrix composites-a review. Composites 16:187-206

9. Yashpal S, Jawalkar CS (2017) Fabrication of aluminium metal matrix composites with particulate reinforcement: a review. Mater Today Proc 4:2927-2936

10. Kumar L, Umasankar V, Elamathi P, Chandrasekar G (2016) Synthesis and characterization of nano hexagonal boron nitride powder and evaluating the influence on aluminium alloy matrix. Mater Today Proc 3:2018-2026

11. Papazian JM, Adler PN (1990) Tensile properties of short fiberreinforced SiC/Al composites. Metall Trans A Phys Metall Mater Sci 21:401-410

12. Zhu YT, Blumenthal WR, Lowe TC (1997) The tensile strength of short fibre-reinforced composites. J Mater Sci 32:2037-2043

13. Tian W, Qi L, Su C, Liang J, Zhou J (2016) Numerical evaluation on mechanical properties of short-fiber-reinforced metal matrix composites: two-step mean-field homogenization procedure. Compos Struct 139:96-103

14. Lloyd D (1994) Particle reinforced aluminium and magnesium matrix composites. Int Mater Rev 39:1-23

15. Kita K, Kondo N (2017) A novel method for joining aluminum and silicon nitride by polysiloxane. J Ceram Soc Jpn 125:543-546

16. Suganuma K (1993) Strength and microstructure of silicon nitride/aluminum interface fabricated by squeeze cast brazing. J Eur Ceram Soc 125:43-49

17. Zhang C, Zeng Y (2017) Enhanced tensile properties of Al matrix composites reinforced with beta-Si3N4 whiskers. Compos Part A 102:145-153

18. Vannan E, Vizhian P (2014) Prediction of the elastic properties of short basalt fiber reinforced al alloy metal matrix composites. J Miner Mater Charact Eng 2:61-69

19. Sharma P, Sharma S, Khanduja D (2015) Production and some properties of Si3N4 reinforced aluminium alloy composites. J Asian Ceram Soc 3:2-9

20. Xiu Z-Y, Chen G-Q, Wu G-H, Yang W-S, Liu Y-M (2011) Effect of volume fraction on microstructure and mechanical properties of $\mathrm{Si}_{3} \mathrm{~N}_{4} / \mathrm{Al}$ composites. Trans Nonferrous Met Soc China 21:S285-S289

21. Arik H (2008) Effect of mechanical alloying process on mechanical properties of alpha- $\mathrm{Si}_{3} \mathrm{~N}_{4}$ reinforced aluminium-based composite materials. Mater Design 29:1856-1861

22. Ramesh C, Keshavamurterhy R, Madhusudhan J (2014) Fatigue behavior of Ni-P coated $\mathrm{Si}_{3} \mathrm{~N}_{4}$ reinforced Al6061 composites. Proc Mater Sci 6:1444-1454

23. Dougherty T, Xu Y, Hanizan A (2016) TMS 2016: 145th annual meeting \& exhibition: supplemental proceedings: supplemental proceedings. https://doi.org/10.1002/9781119274896.ch86

24. Hayward M, Johnston J, Dougherty T, De Silva K (2018) Interfacial adhesion: improving the mechanical properties of silicon nitride fibre-epoxy polymer composites. Compos Interfaces 26:263-273

25. Judge WD (2015) Corrosion behaviour of Alumix 123P/M and AA2014-T6 in 3.5wt\% NaCl. Dalhousie University Halifax, Halifax

26. Zi-yang $X$, Yan-mei $L$ (2009) Effects of extrusion deformation on mechanical properties of sub-micron $\mathrm{Si}_{3} \mathrm{~N}_{4} \mathrm{P} / 2024$ composite. Trans Nonferrous Met Soc China 19:S373-S377 